\title{
ENVIRONMENTAL PERFORMANCE \\ sciendo OF THE TECHNOLOGY OF PRODUCTION \\ OF BIMODAL POLYETHYLENE (HDPE) WITH THE APPLICATION OF LCA TECHNIQUES
}

doi:10.2478/mape-2018-0103

Date of submission of the article to the Editor: 05/2018

Date of acceptance of the article by the Editor: 07/2018

MAPE 2018, volume 1, issue 1, pp. 817-827

\author{
Prof. Magdalena Graczyk \\ PhD., MSc. Leszek Kaźmierczak-Piwko \\ University of Zielona Góra, Poland
}

MA. Grzegorz Ganczewski

COBRO - Institute for Research on Packaging, Poland

\begin{abstract}
The paper discusses the issue of environmental management in chemical industry. The aim of the paper is develop reliable information about environmental footprints of the technology of production of bimodal polyethylene HDPE by means of the diagnostic tool Life Cycle Assessment with the application of the ReCiPe Endpoint $(\mathrm{H})$ method of SimaPro 8.5 software.
\end{abstract}

Keywords: environmental management in chemical industry, environmental performance, environmental footprint

\section{INTRODUCTION}

Chemical industry, considered to be one of the most important branches of national economy, attaches significant attention to shaping appropriate relations with the environment and treats such actions as a matter of priority. Nevertheless, the strongly fixed stereotype of the negative image of technologies used in the chemical sector results in the widespread opinion according to which this branch is particularly 'environmentally aggressive'. This constitutes a serious image problem for the chemical sector requiring strengthening 'preventative marketing' by disseminating the assessment of chemical technologies performed by means diagnostic instruments which guarantee objective, factual and reliable information about their actual Environmental Footprint (EF), and enable to avert unjustified protests or 'false alarms' concerning threats generated by the branch.

It is worth stressing that in recent years the determination of environmental performance as well as its communication to the society have become key tools of environmental management and development of the image of modern companies. Enterprises are becoming increasing more aware that supporting pro-environmental management methods may bring double benefits. On the one hand this means cost cutting by decreasing the consumption of raw materials and media or reducing the risk connected with the change of environmental taxes, on the other hand companies gain image benefits resulting from the improvement of the forms of informing about the environmental performance of products and organizations. Furthermore, improvement of environmental performance in one company to a certain extent enforces implementation of pro-ecological solutions in the subject cooperating with the company, which is particularly important in the context of realization of the concept of sustainable development of economy. 


\section{OPTIONS IN THE APPLICATION OF ASSESSMENT OF ENVIRONMENTAL PERFORMANCE OF TECHNOLOGIES USED IN THE CHEMICAL BRANCH}

While determining environmental performance of technologies, products or semi-products in the chemical branch, two principle issues must be taken into account:

- firstly the current directive of the European Parliament and Council 2010/75 UE of November 24th, 2010 on industrial emissions - IED (The European Parliament and Council, 2010), introducing, among others, the need to apply Best Available Techniques BAT, which to a significant extent decide about the impact of installations on the environment. The Directive tightened the rules on integrated pollution control. BAT conclusions include current standards, and non-adherence is possible only in exceptional situations - if, for example, meeting BAT requirements means disproportionately high costs compared to the benefits for the environment or when the institution issuing integrated permits approves the argumentation and informs the European Committee about such fact (Wiśniewska, 2015). The requirements of the new IED Directive were introduced to the amended Law on environment protection (Dz.U. 2014 poz. 1101, 2014) and the new regulation of the Minister of Environment of August $27^{\text {th }}$, 2014 on types of installations which may cause significant pollution of particular elements of nature or environment as a whole, which replace the previous regulation of 2002 (Dz.U.2014 poz. 1169, 2014).

- secondly - environmental policy, which constitutes one of its priorities, voluntarily and consciously implemented in the chemical sector. It is manifested, among others, by participation in the international program known as 'Responsible Care - RC (Responsible Business Forum). RC program is a 'unique initiative of the global chemical branch, whose aim is to improve health, environmental performance, increase security and communication with stakeholders about products and processes' (CEFIC). The program is based on consistent application of so called code of good practice, and particular companies involved are obliged to introduce actions oriented toward minimisation of the negative impact on the environment, improvement of the level of technological security and protection of health of employees as well as local communities. These actions are defined as the EHS\&S triad environmental, health safety and security (American Chemistry Council). At the beginning of the present century, there occurred another issue, important not only for the chemical industry but also for other branches using and processing chemical semi-products, connected with increasingly more widespread responsibility of manufacturers for their products. Among others, responsibility assumes actions aimed at improving relations with the environment within the e tire life cycle of products - 'from cradle to grave'. In the practice of functioning of firms this means thinking in the categories of life cycle as the basic principle of the Integrated Product Policy (Commission Of The European Communities, 2003), as well as uniform methods of determining environmental performance developed by the European Commitssion and based on the method of Life Cycle Assessment - LCA which, among others, can be widely used, for the purpose of technological assessment of products, services as well as for eco-labelling (The European Commission, 2013). Environmental performance constitutes one of the most advanced ways of determining environmental footprints for products and organizations, and goes beyond the scope of simple statements concerning one environmental aspect e.g. susceptibility to composting or recycling. The implementation of the strategy of resource-efficient and low emission community based on economy which requires thinking in the categories of life cycle at the stages of designing, production, distribution, use, recycling or storage of products which have lost their utility value or are in the phase of 'technological; death', constitutes the prerequisite for large scale implementation of the determination of environmental performance in EU countries. For the purpose of determining environmental performance a universal diagnostic tool is used - Life Cycle Assessment - LCA which enables identification, quantification and assessment of all environmental aspects and potential 
environmental impact, but also determination of places where preventative and/or corrective actions should be initiated.

LCA is also recommended as a reliable instrument for diagnosing quantitative and qualitative impact of products on the environment while developing various types of environmental product statements (Polish Committee for Standardization):

- Type I (standard PN-EN ISO 14024:2018-05E) - based on criteria set by the third party, taking into account product life cycle and applying to numerous aspects, issued by state or private organizations;

- Type II (standard PN-EN ISO 14021:2016-06E) based on the statements of producers or sellers, e.g. product is manufactured in $\mathrm{X} \%$ from recycled materials.

- Type III (standard PN-EN ISO 14025:2010P) based on quantified information about the product based on assessment of the life cycle, which allows for the comparison with other products performing identical functions.

\section{LCA METHODOLOGY OF LIFE CYCLE ASSESSMENT}

The official definition of Life Cycle Assessment was formulated by the Society of Environmental Toxicology and Chemistry - SETAC in 1995 (Allan et al., 1995). According to the definition, it is a technique whose aim is to assess environmental threats connected with the system of manufacturing or operation, both by identification as well as quantitative assessment of materials and energy used, waste introduced into the environment as well as assessment of the impact of materials, energy and waste on the environment. According to Marcinkowski and Zych 'LCA offers a very wide perspective covering various phases of the life cycle' - starting from mining and processing raw materials, through the process of manufacturing, distribution, use, reuse, recycling, final management and transport (Marcinkowski and Zych, 2017).

At present, another definition, formulated by the United National Environment Programme ENEP, is more frequently used in the background literature: $L C A$ is a process of the assessment of the impact exerted by a given product on the environment throughout its life cycle, by means of the increase of the effective use of resources and decrease of the burden on the environment. The assessment of the impact on the environment can be performed both for the product as well as for its functions. LCA is treated as the 'analysis from cradle to grave'. (Kowalski et. al, 2007). LCA methodology is organised in four stages or phases:

1. defining scope and objectives of the study;

2. analysis of inventory;

3. environmental impact assessment;

4. interpretation of results. (Motta et. al., 2018)

According to Mills, Pearce, Farrow, Thorpe and Kirkby "LCA provides tools for determining the best overall options for particular situations and allows innovation and investment resources to be focused accordingly" (Mills et al., 2014). All the above definitions and features of the LCA quoted above stress a system approach and indicate that the aim of the technique is to diagnose complex interactions which occur in subsystems forming the manufacturing process as well as those which occur between the readymade product and the environment, by means of:

- identification of the environmental aspects of processes and documentation of their potential impact on the environment;

- selection of significant indexes for the assessment of environmental performance, while taking into account appropriate measurement techniques;

- determination of the priorities for actions aimed at improvement of the environmental aspects of the technological process and/or products - 'from cradle to grave'.

While appreciating the significance and universal nature of the LCA technique, the International Organization for Standardization - ISO initiated work aimed at unification and objectification of the research methodology presented in standards ISO 1404014044 (Polish 
equivalents are: PN-EN ISO 14040:2009 and PN-EN 14044:2009) (Polish Committee for Standardization, 2009).

According to the methodology presented in a detailed way in the above mentioned standards, LCA analysis covers the entire product life cycle and is performed in four stages (Fig. 1):

- Goal and scope definition,

- LCl - Life Cycle Inventory,

- LCIA - Life Cycle Impact Assessment,

- Interpretation.

The level of specificity of LCA research always depends on the object of analysis and its intended application, jest like determination of limits of the analyzed system comprising particular individual processes. According to the standard an individual process is the smallest part of the system (process tree), for which data is collected during the analysis of the life cycle.

While performing LCA research it is important to specify the product system, which will be the subject of analysis and define product functions as well as the functional unit, which specifies quantitatively identified functions. Functional unit should correspond to the aim and scope of research, and its primary task is to provide reference for standardization of input and output data.

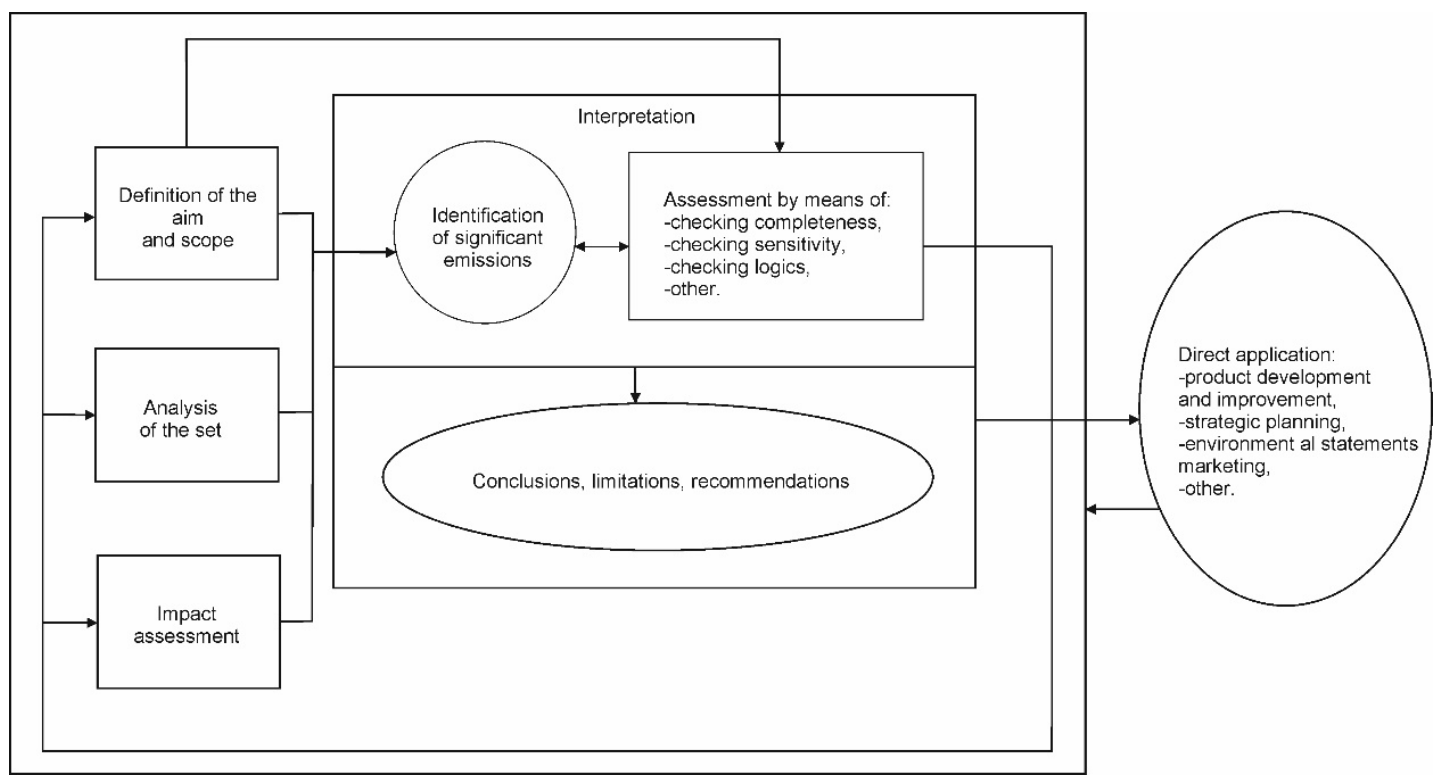

Fig. 1. Stages of assessment of life cycle on the basis of the PN-EN ISO 14040:2009 standard

The most labour intensive and the most difficult stage of LCA consists in the assessment of impact on the environment. The stage includes the assignment of the set data (process tree) to specific categories of impact and is oriented toward understanding and assessment of the volume and significance of the potential impact of the product system on the environment. The stage of the impact assessment can be used for:

- identification of the options for improving product systems and determining the priorities for such options;

- characterization or comparative assessment of product systems and their individual processes in time;

- relative comparison of product systems on the basis of selected indexes of the categories of impact;

- determination of environmental issues, for which other techniques do not provide supplementary environmental data as well as information useful for decision-makers. 
For the purpose of improving Life Cycle Impact Assessment, at present approximately forty commercial computer programs are used, out of which the following three are most popular in view of their application options and widespread use: Umberto offered by ifu Hamburg Productivity meets Sustainability (ifu Hamburg), GaBi developed by 'thinkstep), a consulting company from Leinfelden-Echterdingen in Germany (thinkstep) and SigmaPro developed by PRé Consultants B.V., in the Netherlands (PRé Consultants B.V.).

\section{RESULTS OF THE RESEARCH ON ENVIRONMENTAL PERFORMANCE OF THE TECHNOLOGY OF HIGH DENSITY BI-MODAL POLYETHYLENE (HDPE) WITH THE LCA TECHNIQUE}

Technology of manufacturing Bi-modal polyethylene (HDPE) was subjected to research based on the LCA technique. The choice of this particular material was motivated by its wide use in many branches (among other production of packaging, transmission pipes, household utilities, insulation, elements of casing etc.) In addition, "The HDPE is a non-toxic material (...). It is waterproof and durable if stabilized with UV (ultra violet) radiation agents. It has good mechanical characteristics and is 100\% recyclable, if cleaned" (Dassisti et. al., 2016).

According to the data of the Association of Plastics Manufacturers 'Plastics Europe', global production of plastics (including polyolefin) totalled at 335 million tons in 2016, which means a 4\% increase compared to 2015 (PlasticsEurope, 2017) It has to be noticed, that in the years 2011-2016 the production of plastics increased by $20 \%$ (Fig. 2). High demand for plastics reflects their universal character but also high demand for the material among manufacturers.

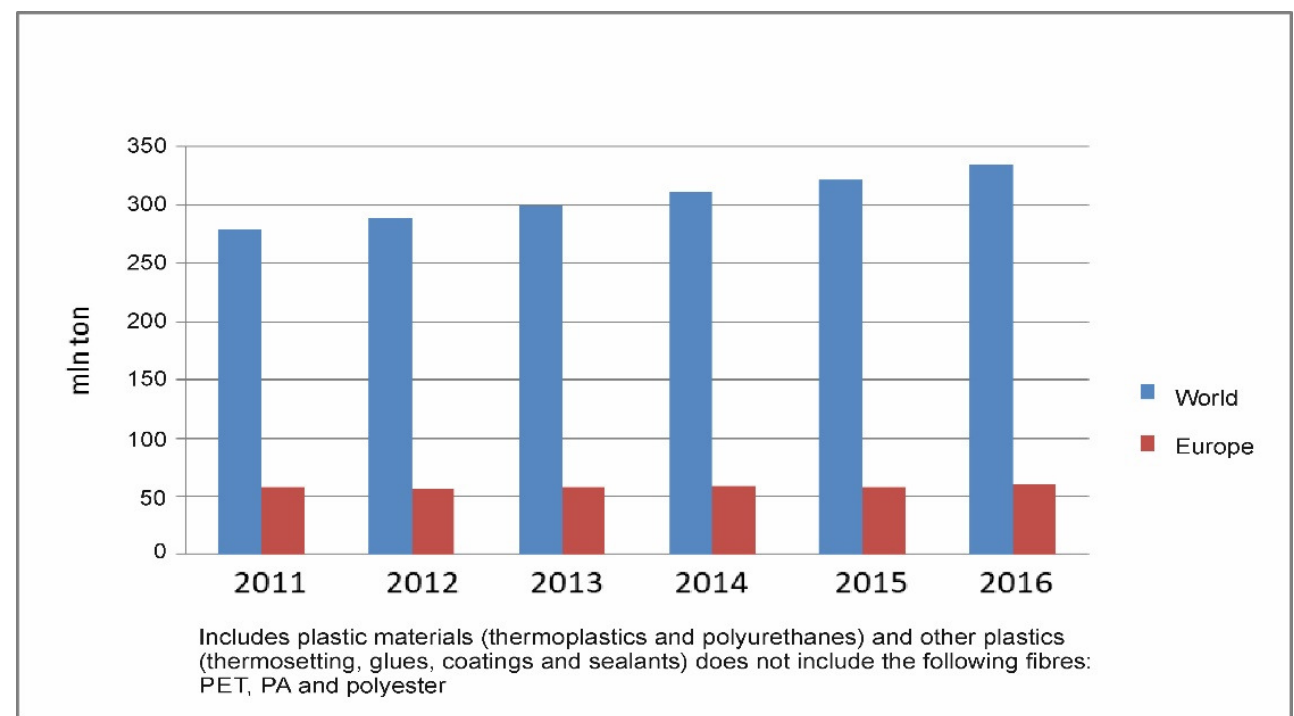

Fig. 2. Production of plastics in the Word and in Europe on the basis of the reports of the Association of Plastics Manufacturers

Source: (PlasticsEurope, 2016; PlasticsEurope, 2017).

While analysing the data presented in Fig. 2, it can be observed that in Europe the production of plastics has remained at a similar level for a long time in the years 2011-2016 and it increased merely by 3.4\%. Polypropylene is most commonly used in Europe, and its share in the consumption amounted and $19.1 \%$, next low density polyethylene $17.3 \%$ and high and medium density polyethylene $12.1 \%$ Further positions are occupied by polyvinyl chloride $10.1 \%$ and polystyrene $6.9 \%$ In Poland the most popular plastics include polyethylene (LDPE, LLDPE, HDPE) with the share in the total consumption of plastics amounting at $30 \%$, next polypropylene $18 \%$, polyvinyl chloride $14 \%$ and polystyrene $14 \%$ (Chemia i Biznes, 2017). In the document EU action plan for Circular Economy approved by the European Commission on December 02, 2015, appropriate management of plastics was given priority (European Commission, 2017) In turn in the European strategy for plastics in Circular Economy, approved 
by the European Commission in January 2018, particular attention was paid to the change of the way in which products are made from plastics are designed, manufactured, used and recycled in the EU (The European Commission, 2018). In the light of the above mentioned documents, determination of the environmental performance based on the Ecological Life Cycle Assessment - LCA enabling the performance of comparative analysis of different variants of production used on the market of plastics becomes even more significant. Life Cycle Assessment of the technology of high density bi-modal polyethylene, taking into account two variants of production, is presented below:

- HDPE production based on 'new' monomers;

- HDPE production involving recycling 'old' de-polymerised plastics.

According to the data of the Association of Plastics Manufacturers, the average value of the recycling packaging made from plastics, amounted in Europe in 2016 at $40.8 \%$, which is significantly above the level of $22.5 \%$ specified in the Packaging Directive (Plastics Europe, 2017).

LCA analysis was performed on the basis of methodology defined in the ISO 140140 standard and covered four stages described below.

\subsection{Stage I - Specification of the aim and scope of research.}

The aim of the research was to determine the impact of the technology of production of high density Bi-modal polyethylene (HDPE) on the environment, considering $13 \%$ recycling of 'old' polyethylene subjected to the process of de-polymerisation. The limits of the system included all raw materials, materials and individual processes forming the 'process tree' of the HDPE technology. The analysis does not include the impact on the environment connected with the construction of machines and facilities, as well as further life stages such as distribution or processing polyethylene into ready-made products - the limits of the system 'from cradle to gate'. $100 \mathrm{~kg}$ of HDPE in the form of granulate was assumed as a functional unit, which was used as reference for input and output data (so called stream of reference).

\subsection{Stage II - Analysis of the set including synthetic description of individual processes forming the technological process}

At this stage, system 'inputs' and 'outputs' were collected and specified quantatively, taking into account particular individual processes forming the 'process tree' of the production of high density bi-modal polyethylene (HDPE) according to the Hostalen technology based on the Advanced Cascade Process - ACP. Hostalen technology is one of the most innovative technolohies in the world. Polymerisation of ethylene in this technology is performed in three reactors connected in series, which allows for the production of polymers of specific characteristics and wide application.

Production of bi-modal polyethylene HDPE is conducted on the basis of suspension process of polymerisation of a monomer - ethylene $\left(\mathrm{C}_{2} \mathrm{H}_{4}\right)$, with the use of organometallic catalysts. The process of preparation of catalysts is gradual, and resulting suspensions of catalyst components in hexane are entered into container reactors with stirrers. Another individual process - polymerisation - is performed continuously in the system of three configurated reactors in the temperature below $85^{\circ} \mathrm{C}$ (below boiling point of hexane) and under pressure not exceeding 10 bars, in the environment of liquid hexane, which performs the function of mass and heat exchage factor. Apart from ethylene, hexane and catalysts, butene is entered to the polymerisation section (for the purpose of regulating appropriate wieght of the polymer) and hydrogene (for the perpose of regulating of molecular weight - index of the speed of flow of polyethylene). Fig. 3 presents the model of analaysis enabling collection of qualitative and quantitative data used at further stages of LCA for ech individual process within the limits of the system of the ACP Hostalen technology. 


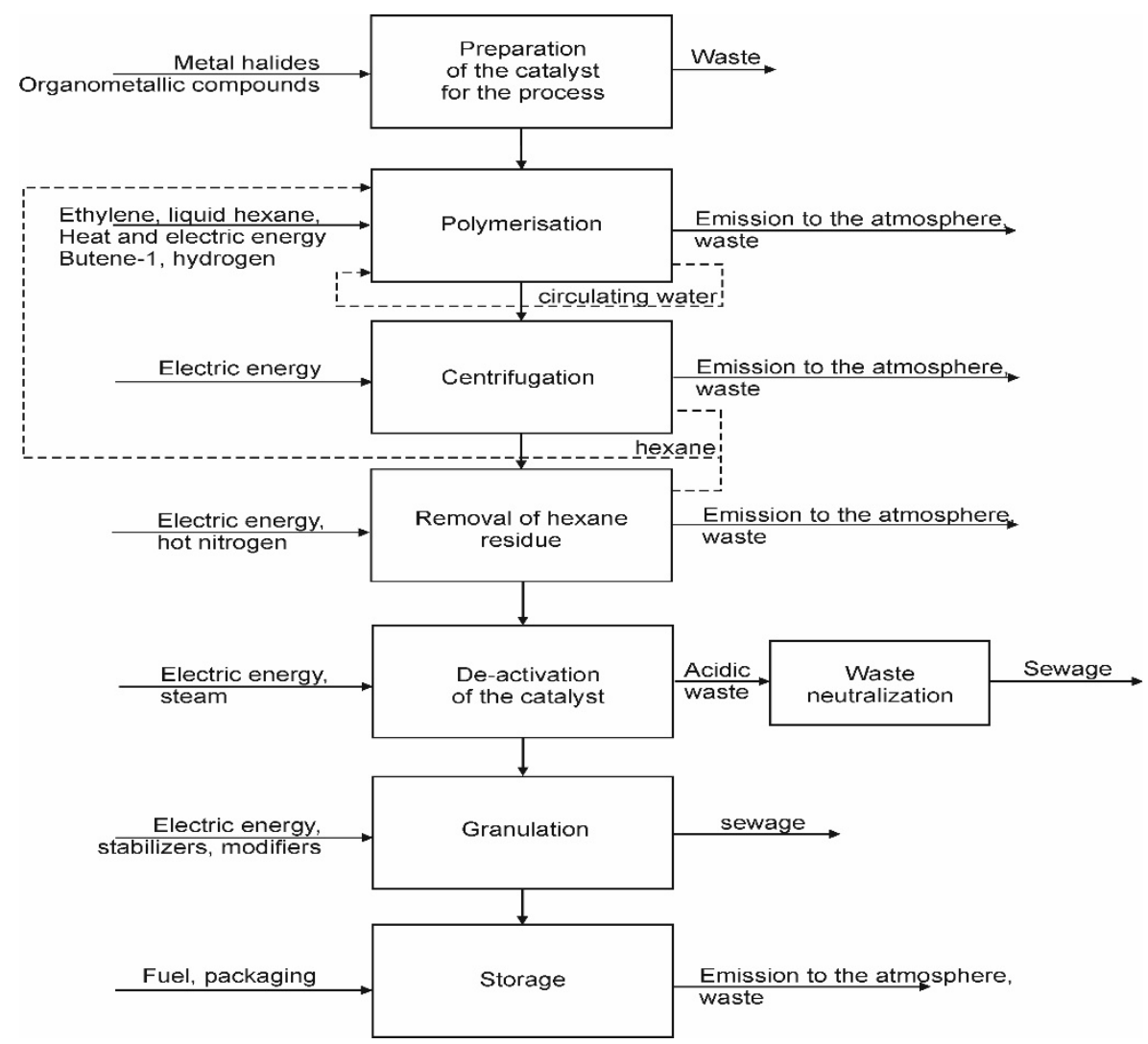

Fig. 3. Process tree of the analysis of the set taking into account material and energy flow in individual processes (horizontal) and between processes (vertical) in HDPE manufacturing

The next individual process in the Hostalen ACP technology consists in spinning the suspension in centrifugal separators in order to separtate hexane and remove its residues in the stream of hot nitrogene, and next blowing through the polymer powder with steam for the purpuse of final deactivation and removal of the remaining catalysts.

During the subsequent individual process stabilizers and modifiers are eneterd into the polymer powder. After mixing them with the powder, the composition is transferred into twin screw extruder, in which fusion, homogenization and granulation of the mixture take place, and next the mixture is packed and delivered to receivers. Polyethylene wax of low molecular weight, which in $100 \%$ is used in the chemical and accessories industry, constitutes a side product of the process. Fig. 4 presents a process tree of the production of polyethylene, taking into account $13 \%$ recycling of 'old' plastics.

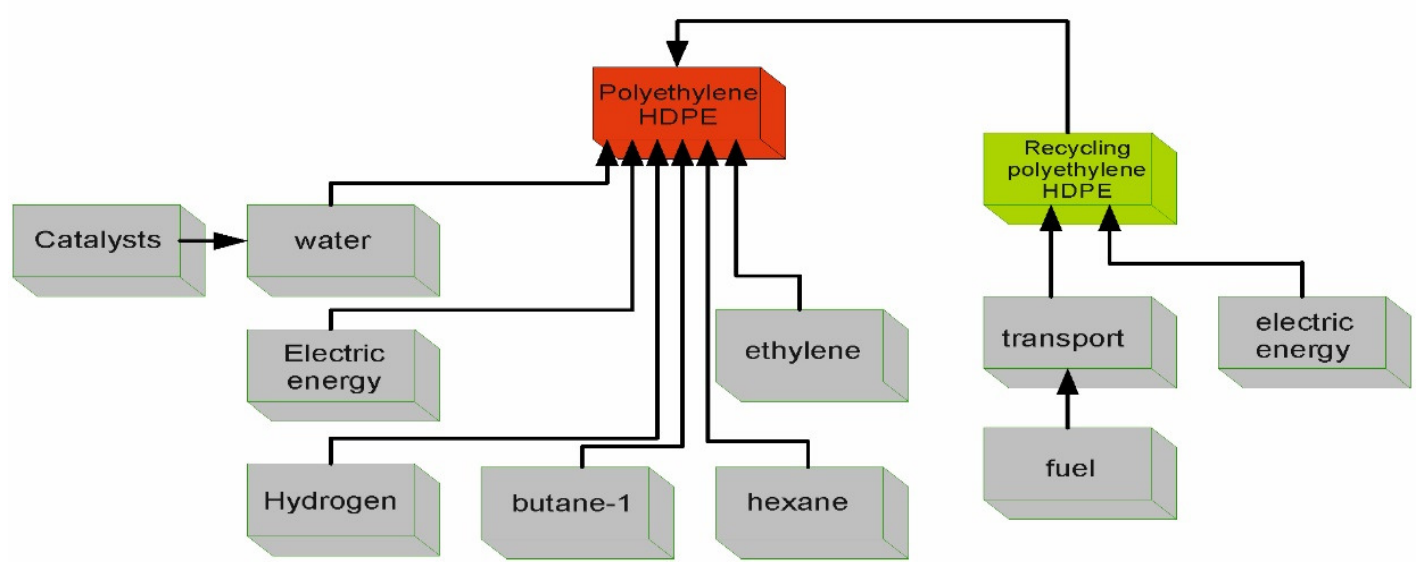

Fig. 4. Process tree of the production of polyethylene, taking into account recycling of old plastics 


\subsection{Stage III - Assessment of the impact on the environment}

Assessment of the impact on the environment was conducted by means of computer software SimaPro 8.5, equipped with a rich library containing standard input data for developing individual projects as well as a search engine offering access to all types of data in the software. For the purpose of assessing the impact on the environment the ReCiPe Endpoint $(\mathrm{H})$ calculation procedure was used, which enable presentation of the cumulated index of the impact on the environment in reference to seventeen categories of impact and/or three categories of damage, taking into account characteristics, standardization and weighting for both process variants $A$ and $B$ (see Table 1 and Fig. 5)

Table 1

LCA result for polyethylene HDPE - in reference to seventeen categories of impact

\begin{tabular}{|l|c|c|c|}
\hline \multicolumn{1}{|c|}{ Categories of impact } & $\begin{array}{c}\text { LCA value of the } \\
\text { process of } \\
\text { production of } \\
\text { polyethylene } \\
\text { variant A - [Pt] }\end{array}$ & $\begin{array}{c}\text { LCA value of the process } \\
\text { of production of } \\
\text { polyethylene, taking into } \\
\text { account recycling - } \\
\text { variant B - [Pt] }\end{array}$ & $\begin{array}{c}\text { Environmental } \\
\text { benefit resulting } \\
\text { from recycling - } \\
\text { [Pt] }\end{array}$ \\
\hline Climate changes - human health & 5.34710 & 4.87054 & -0.47656 \\
\hline Ozone layer depletion & 0.00001 & 0.00004 & 0.00003 \\
\hline Toxicity - people & 0.02907 & 0.08485 & 0.05578 \\
\hline Formation of photochemical oxidisers & 0.00067 & 0.00060 & -0.00007 \\
\hline Formation of particulates & 1.01770 & 0.94855 & -0.06915 \\
\hline lonizing radiation & 0.00001 & 0.00057 & 0.00055 \\
\hline Climate changes - Eco-system & 3.38284 & 3.08133 & -0.30151 \\
\hline Acidification & 0.00760 & 0.00697 & -0.00063 \\
\hline Eutrophication & 0.00027 & 0.00062 & 0.00035 \\
\hline Land Eco-toxicity & 0.00021 & 0.00061 & 0.00040 \\
\hline Eco-toxicity - fresh water & 0.00042 & 0.00115 & 0.00073 \\
\hline Ecotoxicity - sea water & 0.00007 & 0.00021 & 0.00014 \\
\hline Management of agricultural areas & 0.00053 & 0.01354 & 0.01301 \\
\hline Management of Urban areas & 0.00087 & 0.01278 & 0.01191 \\
\hline Transformation of natural areas & -0.00019 & 0.00641 & 0.00661 \\
\hline Consumption of metallic raw materials & 0.00679 & 0.04260 & 0.03581 \\
\hline Consumption of fossil fuels & 17.04263 & 15.04120 & -2.00143 \\
\hline Total & $\mathbf{2 6 . 8 3 6 5 9}$ & $\mathbf{2 4 . 1 1 2 5 5}$ & $\mathbf{- 2 . 7 2 4 0 4}$ \\
\hline
\end{tabular}

The main advantage of this calculation procedure consists in the presentation of the final results of the calculation in the form of a dimensionless number - eco-index points [Pt] and its aliquots, e.g. milli-points [mPt]. It is worth mentioning, that value $1 \mathrm{Pt}$ represents one thousandth of the annual burden on the environment of one citizen of Europe. The value is calculated by dividing the total burden on the environment in Europe by the number of citizens and multiplying it by 1000 (scale index).

While analysing the results of the research by means of the LCA technique, it can be argued that the highest impact on the environment is characterized in both variants by the category consumption of fossil fuels (variant A $17.94 \mathrm{Pt}$, variant B $15.04 \mathrm{Pt}$ ). It has to be stressed however, a clear 'environmental benefit' resulting from the application of recycling in variant $B$, in which in the category of the consumption of fossil fuels, the negative impact on the environment decreased by $2.00 \mathrm{Pt}$. Significant impact on the environment occurs also in the category - climate change - both from the perspective of human health as well as ecosystems (5.34 Pt and 4.87 Pt for climate changes from the perspective of human health respectively and 3.38 Pt and 3.08 Pt for climate changes from the perspective of eco-systems). Also in this category the 'environmental benefit' resulting from recycling is relatively high and is manifested by the decrease of the negative impact by 0.47 and 0.3 Pt respectively. 


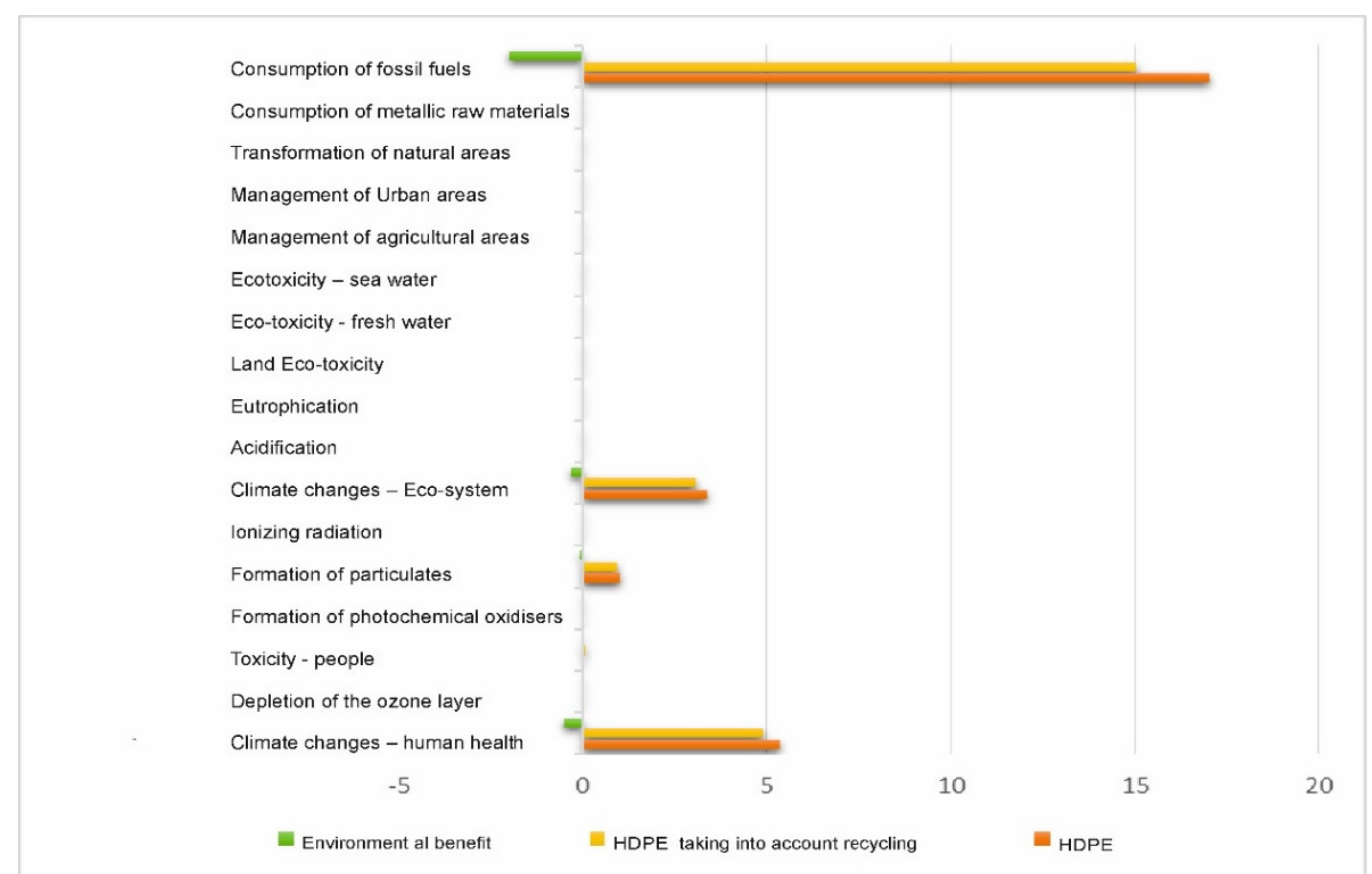

Fig. 5. LCA result for polyethylene HDPE variants $A$ and $B$ - in reference to 17 categories of impact, including environment al benefits resulting from recycling of 'old' plastics (graphic form)

The remaining categories of impact - in case of both analyzed variants, are characterized by lower impact on the environment. Table 2 and Fig. 6 present the assessment of the impact of variants $A$ and $B$ of the production processes of polyethylene HDPE on the environment in reference to three categories of damage.

\section{Table 2}

LCA result for polyethylene HDPE - in reference to categories of damage

\begin{tabular}{|l|c|c|c|}
\hline Categories of damage & $\begin{array}{c}\text { LCA value for the } \\
\text { production process of } \\
\text { polyethylene - variant } \\
\mathbf{A}-[\mathrm{Pt}]\end{array}$ & $\begin{array}{c}\text { LCA value for the } \\
\text { production process of } \\
\text { polyethylene taking into } \\
\text { account recycling - variant } \\
\text { B - [Pt] }\end{array}$ & $\begin{array}{c}\text { Environmental benefit } \\
\text { resulting from the use } \\
\text { of recycling - [Pt] }\end{array}$ \\
\hline Human health & 6.39456 & 5.90514 & -0.48942 \\
\hline Eco-system quality & 3.39261 & 3.12361 & -0.26900 \\
\hline Raw materials & 17.04942 & 15.08380 & -1.96562 \\
\hline Total & $\mathbf{2 6 . 8 3 6 5 9}$ & $\mathbf{2 4 . 1 1 2 5 5}$ & $\mathbf{- 2 . 7 2 4 0 4}$ \\
\hline
\end{tabular}

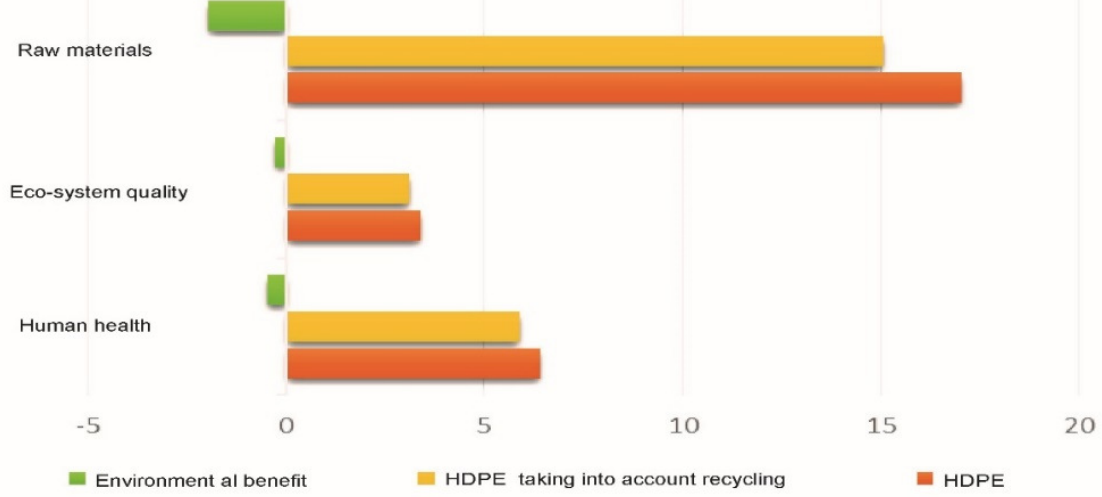

Fig. 6. LCA result for LCA polyethylene HDPE - in reference to three categories of damage (graphic form) 
While comparing quantifiers of the impact on the environent for both variants of the production process HDPE in reference to the three categories of damage, it can be observed the the higherst impact applies to the category raw materials (variant A 17.04 Pt and variant B 15.08 $\mathrm{Pt})$. Both processes are also chracterized by significant impact on the category - human health (6.39 Pt and \%, 90 Pt respectively) The environmental benefit, which is a consequence of the use of recycled 'old' materials amounts at 1.96 and $0.48 \mathrm{Pt}$ respectively.

\section{CONLUSION}

Chemical industry in view of the specific character of manufactured goods is exposed to permanent evalution by consumers, who unfortunately frequently do not have relible data about the impact of the technologies used in this branch on the environment. This unfortunate state of assymetry of information fosters formulation of 'simplified' evaluation of the impact of chemical technologies on human health and natural ecosystems. Hence, development of tools which could determine the directions for improvement of relations between the sector and the environment on the one hand, and guarantee that all the stakeholders are better informed, constitutes a mojor challancge for the industry. The example of the assessment of the technology of $\mathrm{Bi}$-modal polyethylene HDPE shows that the LCA techniques may provide reliable information about the actual environmental footprint, constitute one of the pillars of 'preventative green marketing' and improve eco-efficiency of technologies used in the chemical branch. The comparative analysis of two variants of production of bi-modal polyethylene HDPE enabled a reliable evaluation of 'environmental benefits' in reference to three categories of damage - raw material (use of resources), quality of eco-systems and human heath, and unequivocally quantified the benefits in reference to the applied processes of recycling 'old' materials.

Popularization of the assessment of environmental performance with the use of the LCA technique in the chemical sector may become in the near future not only one of the instruments of improvement of its market image, but also a form of implementation of the principles of resource-efficient and low-emission economy accomplishing the aims of the European Strategy for Plastics in Circular Economy.

\section{REFERENCES}

Allan, D.T. et all,. (1995). Public Policy Applications of Life Cycle Assessment, SETAC Report, Wintergreen.

American Chemistry Council, A Commitment to Health, Safety and Security. [online] Available at: https://responsiblecare.americanchemistry.com [Accessed 24 May. 2018].

CEFIC - The European Chemical Industry Council, The chemical industry's commitment to sustainability. [online] Available at: http://www.cefic.org/Responsible-Care/ [Accessed 25 May 2018].

Chemia i Biznes. (2017) Rynek tworzyw sztucznych w Europie. [online] Available at: http://www.chemiaibiznes.com.pl/aktualnosc/rynek-tworzyw-sztucznych-w-europie [Accessed 21 May 2018].

Commission Of The European Communities. (2003), 2003COM (2003) 302 final Communication From The Commission On The Council And The European Parliament: - Integrated Product Policy. Building on Environmental Life-Cycle Thinking, Brussels 18.06.2003.3. [online] Available at: http://ec.europa.eu/transparency/regdoc/rep/1/2003/EN/1-2003-302-EN-F1-1.Pdf [Accessed 29 Jan. 2018]

Dassisti, M., Intini, F., Chimienti, M. and Starace, G., Thermography-enhanced LCA (Life Cycle Assessment) for manufacturing sustainability assessment. The case study of an HDPE (High Density Polyethylene) net company in Italy. Energy [online] 108 (2016) p. 7-18, Available at: https://doi.org/10.1016/j.energy.2016.01.043 [Accessed 20 Jun. 2018]

Dz.U. 2014 poz. 1101, (2014). Ustawa z dnia 11 lipca 2014 r. o zmianie ustawy - Prawo ochrony środowiska oraz niektórych innych ustaw [online] Available at: http://prawo.sejm.gov.pl/isap.nsf/DocDetails.xsp?id=WDU20140001101] [Accessed 17 March 2018].

Dz.U.2014 poz. 1169. (2014), Rozporządzenie Ministra Środowiska z dnia 27 sierpnia 2014 r. w sprawie rodzajów instalacji mogących powodować znaczne zanieczyszczenie poszczególnych elementów przyrodniczych albo środowiska jako całości. [online] Available at: http://prawo.sejm.gov.pl/isap.nsf/DocDetails.xsp?id=WDU20140001169 
ifu Hamburg - Productivity meets Sustainability, LCA Software. [online] Available at: www.ifu.com [Accessed 25 May 2018].

Kowalski Z., Kulczycka J. and Góralczyk M. (2007). Ekologiczna ocena cyklu życia procesów wytwórczych (LCA). Warszawa: Wydawnictwo Naukowe PWN.

Marcinkowski, A and Zych, K. (2017). Environmental performance of kettle production: Product Life Cycle Assessment. Management Systems in Production Engineering, [online] Volume 25, Issue 4, pp 255-261. Available at: https://content.sciendo.com/view/journals/mspe/25/4/article-p255.xml [Accessed 23 May 2018].

Mills, N., Pearce, P., Farrow, J., Thorpe, R.B. and Kirkby, N.F.,( 2014) Environmental \& economic life cycle assessment of current \& future sewage sludge to energy technologies. Waste Management, [online] Volume 34, Issue 1, January 2014, p. 185-195. Available at: https://doi.org/10.1016/j.wasman.2013.08.024 [Accessed 20 Jun. 2018].

Motta, W.H, Issberner, LR. and Prado, P., (2018). Life cycle assessment and eco-innovations: What kind of convergenceis possible?. Journal of Cleaner Production, [online] 187 (2018) p. 1103-1114, Available at: https://doi.org/10.1016/j.jclepro.2018.03.221 [Accessed 20 Jun. 2018].

Najlepsze dostępne techniki (BAT), wytyczne dla Branży Chemicznej w Polsce. Przemysł Polimerów, (2005). Ministerstwo Środowiska, Warszawa. [online] Available at: https://ippc.mos.gov.pl/ippc/?id=315

PlasticsEurope. (2016), Plastics - the Facts 2016, An analysis of European plastics production, demand and waste data, Association of Plastics Manufacturers - PlasticsEurope. [online] Available at: https://www.plasticseurope.org/application/files/4315/1310/4805/plastic-the-fact2016.pdf[Accessed 12 May 2018].

PlasticsEurope. (2017), Plastics - the Facts 2017, An analysis of European plastics production, demand and waste data, Association of Plastics Manufacturers PlasticsEurope. [online] Available

at: https://www.plasticseurope.org/application/files/5715/1717/4180/Plastics the facts 2017 FINA L_for_website_one_page.pdf [Accessed 12 May 2018].

Polish Committee for Standardization. (2009) PN-EN ISO 14044:2009, Environmental management Life cycle assessment - Requirements and guidelines.

Polish Committee for Standardization. List of current PN PN. [online] Available at: https://pzn.pkn.pl/kt/info/published/9000128755 [Accessed 22 May 2018].

PRé Consultants B.V. Sustainability software for fact-based decision making. [online] Available at:https://www.pre-sustainability.com [Accessed 25 May 2018].

Responsible Business Forum, Program „Responsible Care” - Henkel Poland. [online] Available at: http://odpowiedzialnybiznes.p [Accessed 25 May 2018].

The European Commission. (2013). COMMISSION RECOMMENDATION of 9 April 2013 on the use of common methods to measure and communicate the life cycle environmental performance of products and organisations (2013/179/EU), Official Journal of the European Union L 124/1. [online] Available at: http://data.europa.eu/eli/reco/2013/179/oj [Accessed 25 Apr. 2018].

The European Commission. (2017). European Commission - Press release, Circular Economy: Commission delivers on its promises, offers guidance on recovery of energy from waste and works with EIB to boost investment, Brussels, 26 January 2017. [online] Available at: http://europa.eu/rapid/press-release_IP-17-104_en.htm [Accessed 22 May 2018].

The European Commission. (2018). Brussels, 16.1.2018 COM(2018) 28 final COMMUNICATION FROM THE COMMISSION TO THE EUROPEAN PARLIAMENT, THE COUNCIL, THE EUROPEAN ECONOMIC AND SOCIAL COMMITTEE AND THE COMMITTEE OF THE REGIONS, A European Strategy for Plastics in a Circular Economy SWD(2018) 16 final. [online] Available at: http://ec.europa.eu/environment/circular-economy/pdf/plastics-strategy-swd.pdf [Accessed 5 May 2018].

The European Parliament and Council. (2010). Directive 2010/75/EU of the European Parliament and of the Council of 24 November 2010 on industrial emissions (integrated pollution prevention and control). Official Journal of the European Union L 334/17. [online] Available at: https://eurlex.europa.eu/legal-content/PL/TXT/?uri=celex\%3A32010L0075 [Accessed 5 May 2018].

thinkstep - Sustainability Consulting and Software, Sustainability Software. [online] Available at: https://www.thinkstep.com [Accessed 23 May 2018].

Wiśniewska, E. (2015). Najlepsze dostępne techniki BAT jako instrument ochrony środowiska. Inżynieria i Ochrona Środowiska, t. 18, nr 3, s.385-397. 